\title{
Medicinal and therapeutic properties of cephalopod ink: a short review
}

\author{
${ }^{1}$ Hossain, M.P., ${ }^{1 *}$ Rabeta, M.S. and ${ }^{2}$ Husnul Azan, T. \\ ${ }^{1}$ Food Technology Division, School of Industrial Technology, Universiti Sains Malaysia, 11800 Minden, \\ Penang, Malaysia \\ ${ }^{2}$ Bioprocess Technology Division, School of Industrial Technology, Universiti Sains Malaysia, 11800 \\ Minden, Penang, Malaysia
}

\author{
Article history: \\ Received: 12 July 2018 \\ Received in revised form: 25 \\ August 2018 \\ Accepted: 26 August 2018 \\ Available Online: 9 \\ September 2018 \\ Keywords: \\ Cephalopod, \\ Ink, \\ Antimicrobial, \\ Anti-cancer, \\ Antioxidant
}

DOI:

https://doi.org/10.26656/fr.2017.3(3).201

\begin{abstract}
Cephalopoda is under the phylum of Mollusca with several important marine oceanic habitats. They are mostly well-known for their different uses such as food ingredients and nutraceutical benefits. Among all the different habitats of this class, different species of squid and cuttlefish often containing various nutraceutical properties along with the use as a food item. Surprisingly, the ink of these different species of cephalopods also contains different nutraceutical properties which are thrown away as by-product by most of the processing industries and consumers. There are different studies which focused on these properties obtained from the ink of these cephalopods. These studies clearly showed that this ink is a great source for decreasing various health problems and can be used widely in both pharmaceuticals and food industries. The aim of this review is to focus on its potentials and make it an evident towards the future uses of cephalopod ink.
\end{abstract}

\section{Introduction}

Cephalopods live in the marine environment and the number of cephalopod species is relatively low (approximately 700) compared to the number of other species; however, they are widely distributed in different marine habitats (Nair and Sherief, 2010; Derby, 2014). Nautiloidea (nautilus) and Coleoidea are the two major groups that represent cephalopods (Derby 2014), which include squids, cuttlefish, octopus and nautilus (Nair and Sherief, 2010). Among those, squid is the major constituent of the Cephalopoda class (Normal et al., 2002). Currently, squid and cuttlefish are an important fishery product all over the world, especially in Southeast Asian countries (Hoque et al., 2010). Cephalopods have historically been used as human food, especially among Greeks and Egyptians, in different ways (Sundaram, 2009).

Primarily in India, cephalopods were used in the dried form (Rao, 1954; Vijayakumaran, 1984). In the Philippines, cephalopods are first boiled in vinegar and are then fried in oil and spices (Voss, 1963). Squids are incorporated with fish stew in Britain to increase taste (Cornell and Handy, 1982). The Japanese have mastered the use of different varieties of cephalopods in various dishes (Silas et al., 1985). Moreover, other varieties of cephalopods are popular as food dishes food such as pickles (Sundaram, 2009).

During the processing of squids and cuttlefish, the viscera and ink sac containing the ink are considered byproducts and are potential threats for creating serious ecological problems as well as environmental pollution without proper management. These by-products can be a potential source of bioactive compounds and have been proven to be an alternative medicine with a wide range of therapeutic applications. The utilization of these byproducts will benefit the processing industry as well as reduce serious ecological problems and pollution (McConnell et al., 1993; Karim et al., 2016).

Most cephalopods, excluding nautiloid, have ink sacs and thus produce ink (Hanlon and Messenger, 1996). Cephalopod species that live in low light, including deep sea areas, produce and use ink (Bush et al., 2007). Even when cephalopods are small and young, ink sacs can be present and produce ink (Boletzky, 1987). In Japan, squid ink has traditional applications in food products (Nishimoto et al., 1980). In addition, it is believed that 'Ika-shiokara,' which is a cured cuttlefish meat produced in Japan exhibits anti-septic effect when cuttlefish ink added to it (Takai et al., 1993). Cephalopod ink has already been reported for its various 
therapeutic values (Takai et al., 1992). The crude ink extracts from various species of cephalopods have been studied for their antimicrobial, preservative, antioxidant, anti-cancer, antiretroviral and many other properties (Mochizuki, 1979; Takai et al., 1992; Takaya et al., 1994; Sasaki et al., 1997; Rajaganapathi et al., 2000; Russo et al., 2003; Sadok et al., 2004; Yang et al., 2005; Lei et al., 2007; Girija et al., 2008). These properties make cephalopod ink attractive. In this review, we attempt to combine all these properties to determine the potential prospects of using cephalopod ink in different ways.

\section{Cephalopods ink and its components}

Cephalopod ink is a natural substance discharged by cephalopods from their ink sac when they confront enemies and try to escape from predators (Ortonne et al., 1981; Lei et al., 2007). The release of dark ink is used as a defensive means to avoid enemies and risks (Liu et al., 2011; Nicomrat and Tharajak, 2015). The ejected ink helps cephalopods to confuse predators and sends a signal to other cephalopods about the danger (Lucero et al.,1994)

Cephalopod ink consists of a suspension of melanin granules in a viscous colourless medium. In the mantle cavity, the ink gland cells of the digestive tract degenerate and shed their content into the ink sac, which is used as a reservoir for the ink. The production and ejection of the ink seem to be regulated by the glutamate/ nitric oxide/cGMP signaling pathway located in the ink gland (Palumbo et al., 1997; Palumbo et al., 2000; Liu et al., 2011). In addition to a large amount of melanin, the ink also contains proteins, lipids, glycosaminoglycans and various metals (Copper, Cadmium). (Lei et al., 2007; Liu et al., 2011; Zhong et al., 2009). It also contains a variety of melanogenic enzymes, including tyrosine, which is a dopachrome-rearranging enzyme (Palumbo et al., 1998).

\section{Different medicinal and therapeutic properties of cephalopod ink}

\subsection{Antimicrobial activity}

Different studies have been conducted to determine the antimicrobial activities of different squid inks. Nirmale et al. (2002), suggested that the freeze-dried and precipitated ink of the Indian squid Loligo duvauceli has good antibacterial effects. It mostly showed strong antibacterial effects against gram-negative bacteria, Salmonella spp. Escherichia coli, Vibrio cholerae, V. parahaemolyticus and Pseudomonas spp. However, the effects of the gram-positive bacteria Staphylococcus spp. and Micrococcus spp. are weaker than the effects against gram-negative bacteria. Giriji et al. (2011), reported on a novel antimicrobial protein, Lolduvin-s, which was isolated from the ink of Indian squid (Loligo duvauceli) and showed promising antibacterial and antifungal activities against different pathogens. Girija et al. (2014), revealed that squid (L. duvauceli) ink extract has antibacterial potential against dental caries pathogens. It has also been reported that squid ink has good antibacterial properties against extended spectrum betalactamase (ESBL)-producing strains of E. coli and Klebsiella pneumonia (Girija et al., 2012). Karim et al. (2016) suggested that squids treated with $0.25 \%$ squid ink showed very low growth of bacteria during storage at $4^{\circ} \mathrm{C}$. Nicomrat and Tharajak (2015) found that squid ( $L$. duvauceli) and soft cuttlefish (Sepioteuthis lessoniana) ink have strong antimicrobial activity against biofilms causing microorganisms.

Mochizouki (1979), reported that cuttlefish ink has an inhibitory effect on Staphylococcus aureus and has antiseptic properties. The ink of pharaoh cuttlefish, Sepia pharaonic, has antibacterial effects against human pathogens such as Pseudomonas aeruginosa, Staphylococcus epidermidis, K. pneumonia and E. coli. In these cases, researchers have found that crude ink extracted in hexane and column-purified ink extracted in diethyl ether show maximum inhibitory effects against these pathogens (Nithya et al., 2011). Vennila et al. (2010), reported that cuttlefish (Sepia aculeate) ink and squid (L. duvauceli) ink have antifungal effects against Fusarium spp. and Aspergillus fumigates. Diaz and Thilaga (2016), revealed that crude and partially purified ink extracts of squid (L. duvauceli) and cuttlefish (Sepia pharaonis) have antibacterial effects against eight different bacterial strains. Table 1 represents a brief information about different in research on antimicrobial properties of cephalopod ink. Ink from different species of cephalopods had been used for studying antimicrobial properties of the ink. Various pathogenic bacteria and microorganisms are used in these studies, a list of that microorganisms also included in Table 1 . In most of the studies, different kinds of ink samples showed prominent antimicrobial activities against most of the pathogenic bacteria which made cephalopod ink a very good antimicrobial agent and thus it became an object of attraction among researchers.

\subsection{Anti-cancer activity}

Squid and cuttlefish ink has the potential to act as anticancer agents, and this is based on in vitro studies of cancer cell line. The anti-cancer effects of squid and cuttlefish ink occur through the initiation of apoptosis and are affiliated with different chemicals of ink (Derby, 2014). 
Table 1. Antimicrobial properties of cephalopods ink

\begin{tabular}{|c|c|c|c|c|}
\hline $\begin{array}{c}\text { Name of } \\
\text { cephalopods }\end{array}$ & Mode of ink preparation & Microorganism & Results & References \\
\hline $\begin{array}{c}\text { Cuttlefish }(S . \\
\text { pharaonis) }\end{array}$ & $\begin{array}{l}\text { - Fridge dried crude ink } \\
\text { - Partially purified ink } \\
\text { by ammonium } \\
\text { sulphate }\end{array}$ & $\begin{array}{l}\text { - S. aureus (ATCC 25923) } \\
\text { - B. subtilis (MTCC 441) } \\
\text { - P. aeruginosa (ATCC } \\
\text { 27853) } \\
\text { - A. hydrophila, } \\
\text { - S. pyogenes, } \\
\text { - V. fischeri } \\
\text { - } \text { K. pneumonia (ATCC } \\
\text { 15380) } \\
\text { - E. coli (ATCC 25922) } \\
\text { - C. albicans (MTCC 227) } \\
\text { (Fungal strain) }\end{array}$ & $\begin{array}{l}\text { - } 100 \mu \mathrm{L} \text { crude ink concentration } \\
\text { of both squid and cuttlefish had } \\
\text { good activity against all sample } \\
\text { microorganism. } \\
\text { - } 20 \mu \mathrm{L} \text { concentration had good } \\
\text { activity only against } V \text {. fischeri } \\
\text { (squid ink) and } K . \text { pneumonia, } \\
\text { A. hydrophila (cuttlefish ink). } \\
\text { - Only two fractions ( } 30 \% \text { and } \\
40 \% \text { of partially purified squid } \\
\text { ink and one fraction ( } 80 \% \text { ) } \\
\text { partially purified cuttlefish ink } \\
\text { exhibited activity. }\end{array}$ & $\begin{array}{l}\text { Diaz and } \\
\text { Thilaga } \\
(2016)\end{array}$ \\
\hline $\begin{array}{c}\text { Soft } \\
\text { cuttlefish } \\
\text { (Sepioteuthis } \\
\text { lessoniana) }\end{array}$ & $\begin{array}{l}\text { - Crude ink pretreated } \\
\text { with different } \\
\text { temperature (Room } \\
\text { temp, } 40,60,80,100 \\
\left.{ }^{\circ} \mathrm{C}\right) \text { for } 15 \text { minutes }\end{array}$ & $\begin{array}{l}\text { - E. coli (ATCC 338849) } \\
\text { - S. aureus (ATCC 12600) } \\
\text { - B. subtilis (D83357) } \\
\text { - } \quad \text { P. aeruginosa (ATCC } \\
\text { 14886) } \\
\text { - A. fumigatus (Af293) } \\
\text { (Fungus) } \\
\text { - S. cerevisiae (ATCC } \\
\text { 204508) (Yeast) }\end{array}$ & $\begin{array}{l}\text { - Both squid and cuttlefish ink } \\
\text { had good activity, but squid ink } \\
\text { had more than the cuttlefish } \\
\text { ink. } \\
\text { - Ink pretreatment from Room } \\
\text { temperature to } 60{ }^{\circ} \mathrm{C} \text { had more } \\
\text { antimicrobial activity than high } \\
\text { temperature treated ink. }\end{array}$ & $\begin{array}{c}\text { Nicomrat et } \\
\text { al. (2015) }\end{array}$ \\
\hline Squid & $\begin{array}{l}\text { - Crude ink extracted } \\
\text { with different solvents } \\
\text { (Acetone, Ether, } \\
\text { Butanol, Hexane, } \\
\text { Ethanol, Methanol, } \\
\text { Chloroform, Ethyl } \\
\text { acetate) }\end{array}$ & $\begin{array}{l}\text { - E. coli (ESBL strain) } \\
\text { - K. pneumonia (ESBL } \\
\text { strain) }\end{array}$ & $\begin{array}{l}\text { - Hexane extract of squid ink } \\
\text { showed good antibacterial } \\
\text { activity against both organisms. }\end{array}$ & $\begin{array}{l}\text { Giriji et al. } \\
\text { (2011) }\end{array}$ \\
\hline $\begin{array}{l}\text { Indian squid } \\
\qquad(L . \\
\text { duvauceli) }\end{array}$ & $\begin{array}{l}\text { - Crude ink extracted } \\
\text { with different solvents } \\
\text { (hexane, ethyl acetate, } \\
\text { acetone, diethyl ether } \\
\text { and chloroform) }\end{array}$ & $\begin{array}{l}\text { - L. acidophilus } \\
\text { - S. mutans } \\
\text { - A. viscosus } \\
\text { - C. albicans } \\
\text { - (All bacterial pathogens } \\
\text { are isolated from carious } \\
\text { dentine) }\end{array}$ & $\begin{array}{l}\text { - Only hexane extract of crude } \\
\text { squid ink showed good } \\
\text { antibacterial properties against } \\
\text { all these dentine pathogens. } \\
\text { - }\end{array}$ & $\begin{array}{c}\text { Girija et al., } \\
\quad(2014)\end{array}$ \\
\hline $\begin{array}{l}\text { Indian squid } \\
\qquad(L . \\
\text { duvauceli })\end{array}$ & $\begin{array}{l}\text { - Antimicrobial protein } \\
\text { named Lolduvin-S } \\
\text { isolated from squid } \\
\text { ink and subjected for } \\
\text { antimicrobial test. }\end{array}$ & $\begin{array}{l}\text { - } \text { E. coli (ESBL strain) } \\
\text { - } \text { K. pneumonia (ESBL } \\
\text { strain) } \\
\text { - S. aureus (methicillin- } \\
\text { resistant) } \\
\text { - } \text { C. albicans (Amphotericin } \\
\text { B resistant) }\end{array}$ & $\begin{array}{l}\text { - Isolated protein from squid ink } \\
\text { showed significant activity } \\
\text { against all the organisms. }\end{array}$ & $\begin{array}{l}\text { Girija et al., } \\
\quad(2011)\end{array}$ \\
\hline $\begin{array}{l}\text { Indian squid } \\
\qquad(L . \\
\text { duvauceli })\end{array}$ & $\begin{array}{l}\text { - Squid ink sample was } \\
\text { produced by different } \\
\text { method like fridge } \\
\text { drying, vacuum } \\
\text { drying and } \\
\text { precipitation at } \\
\text { different } \mathrm{pH}\end{array}$ & $\begin{array}{l}\text { - Salmonella spp. } \\
\text { - Pseudomonas spp. } \\
\text { - V. cholerae } \\
\text { - E. coli } \\
\text { - V.parahaemolyticus } \\
\text { - Staphylococcus spp. } \\
\text { - Micrococcus spp. } \\
\text { - P. leiognathi }\end{array}$ & $\begin{array}{l}\text { - Fridge dried and precipitated } \\
\text { ink show good activity against } \\
\text { gram-positive bacteria. } \\
\text { - No activity against gram- } \\
\text { negative bacteria. }\end{array}$ & $\begin{array}{l}\text { Nirmale et } \\
\text { al. }(2002)\end{array}$ \\
\hline
\end{tabular}


Table 1 (Continued). Antimicrobial properties of cephalopods ink

\begin{tabular}{|c|c|c|c|c|}
\hline $\begin{array}{c}\text { Name of } \\
\text { cephalopods }\end{array}$ & Mode of ink preparation & Microorganism & Results & References \\
\hline $\begin{array}{l}\text { Squid (L. } \\
\text { duvauceli) }\end{array}$ & $\begin{array}{l}\text { Aqueous extract of } \\
\text { crude ink of squid, } \\
\text { cuttlefish, and octopus } \\
\text { were used. }\end{array}$ & $\begin{array}{l}\text { - Fusarium spp. (mold) } \\
\text { - Aspergillus fumigates } \\
\text { (mold) } \\
\text { - Pseudomonas aeruginosa } \\
(\mathrm{G}+) \\
\text { - Staphylococcus aureus }(\mathrm{G} \\
+)\end{array}$ & $\begin{array}{l}\text { - Squid, cuttlefish and octopus } \\
\text { ink showed good antifungal } \\
\text { activity. } \\
\text { - But these ink samples did not } \\
\text { show good antibacterial } \\
\text { activity against the test } \\
\text { pathogens. }\end{array}$ & $\begin{array}{c}\text { Vennila et al. } \\
(2010)\end{array}$ \\
\hline $\begin{array}{l}\text { Cuttlefish } \\
\text { (Sepia } \\
\text { aculeate) }\end{array}$ & & $\begin{array}{l}\text { - V. cholerae (G-) } \\
\text { - Salmonella enterica } \\
\text { serovar Paratyphi (G -) }\end{array}$ & & \\
\hline $\begin{array}{l}\text { Octopus } \\
\text { (Octopus } \\
\text { vulgaris) }\end{array}$ & & $\begin{array}{l}\text { - Shigella boydii }(\mathrm{G}-) \\
\text { - Shigella dysenteriae (G -) } \\
\text { - K. pneumonia }(\mathrm{G}-)\end{array}$ & & \\
\hline $\begin{array}{l}\text { Cuttlefish } \\
\qquad(S . \\
\text { pharaonis })\end{array}$ & $\begin{array}{l}\text { - Crude ink extracted } \\
\text { by acetone, } \\
\text { chloroform, butanol, } \\
\text { hexane } \\
\text { - Partial purification of } \\
\text { ink was also done by } \\
\text { normal phase silica } \\
\text { gel column } \\
\text { chromatography. }\end{array}$ & $\begin{array}{l}\text { - Escherichia coli } \\
\text { - Citrobacter spp. } \\
\text { - K. pneumonia } \\
\text { - S. epidermidis } \\
\text { - P. aeruginosa }\end{array}$ & $\begin{array}{l}\text { - Crude ink extract in hexane and } \\
\text { column purified ink extract in } \\
\text { diethyl ether showed the } \\
\text { highest activity against all test } \\
\text { microorganisms. }\end{array}$ & $\begin{array}{c}\text { Nithya et al. } \\
\text { (2011) }\end{array}$ \\
\hline
\end{tabular}

Diaz et al. (2014), evaluated the anti-cancer activity of squid ( $L$. duvauceli) ink. Crude and partially purified squid ink was used on the Hep G2 cell line, and cell viability and cell proliferation assays were performed. They revealed having good anti-carcinogenic activity of partially purified $L$. duvauceli ink on the HepG2 cell line.

Takaya et al. (1994), reported on the antitumour peptidoglycan fraction of squid ink obtained from Illex argentinus. Tris- $\mathrm{HCl}$ buffer $(\mathrm{pH}$ 6.8) was used for the extraction and the fractionation of the ink to obtain the peptidoglycan fraction. Strong antitumour activity was found by applying it against Meth-A fibrosarcoma in $\mathrm{BALB} / \mathrm{c}$ mice. As the fraction of squid ink has no direct cytotoxic effect against Meth-A cells, the stimulation of host-mediated responses may be the reason for the suppression of tumour growth. Sasaki et al. (1997), also studied the antitumour activity of the peptidoglycan fraction of squid (I. argentinus) ink, which was delipidated in acetone and used against Meth-A tumours from BALB/c mice, and they found $64 \%$ cure rate against Meth-A tumours. Later, Naraoka et al. (2000) showed that there are two different components that are responsible for the anti-tumour activity of squid ink. They suggested that illexin-peptidoglycan, tyrosinase and the complex of these two are responsible for the antitumour activity of squid ink, and the complexity of the two components showed the highest antitumour activity against Meth-A tumour cells of BALB/c mice.
Zhong et al. (2009) worked on the protective effects of squid ink in chemotherapy. In the study, BALB/c mice were used as animal models, and injuries were induced by cyclophosphamide. This study showed positive results for the protection of the haemopoietic system from chemotherapeutic injury and suggested that it could be employed to develop cell protective drugs for use in clinical treatment of tumours.

Chen et al. (2010) reported that chemically sulphated polysaccharides (SIPs) isolated from squid (Ommastrephes bartrami) ink have good antitumour activity against HepG2 tumour cells. Both in vitro and in vivo studies provide substantial proof that SIPs have potential compounds for the prevention of tumour metastasis.

Senan et al. (2013a) suggested that ink extracts of different cuttlefish species, such as Sepia pharaonis, Sepia aculeate, Sepiella inermis and squid ( $L$. duvauceli), that were delipidated in acetone and extracted by Tris-HCl buffer have potential antiproliferative effects against chick embryo fibroblast cells, which provides proof of the potential use of the ink extracts as an anticancer agent. Another study by Senan et al. (2013b) provided information about the anticancer activity of the purified C2 fraction of $S$. pharaonis ink against cervical cancer cell lines-HeLa and Caski. Fahmy and Soliman (2013) reported that cuttlefish (Sepia officinalis) ink extract has cytotoxic activity and can be used as promising anticancer drugs, which was 
determined using the sulphorhodamine B (SRB) method against hepatocellular carcinoma (HepG2) cell line. Soliman et al. (2015) found that S. officinalis ink extract had anticancer effects against Ehrlich ascites carcinoma (EAC) in Swiss albino mice. He added that Sepia ink extract inhibits tumour growth in the ascites tumour model. Russo et al. (2003) applied melanin-free $S$. officinalis ink on various cell lines, including PC12 cells, and found that it was cytotoxic to the PC12 cell lines and could be used in future carcinogenic drugs.

Guo-Fang et al. (2011) performed enzymatic hydrolysis of $S$. officinalis ink using trypsin enzyme and isolated an oligopeptide from hydrolysates, which have anticancer activities. These potential anticancer properties were proved when the isolated oligopeptide from Sepia ink hydrolysates were used against human prostate carcinoma cells (DU-145). Huang et al. (2012) reported that Sepia ink oligopeptide (SIO), which is a tripeptide extracted from Sepia esculenta ink, inhibits prostate cancer by inducing apoptosis. SIO was applied against three human prostate cell lines DU-145, PC-3 and $\mathrm{LNCaP}$ to prove the potency of SIO as an anticarcinogenic agent.

Wang et al. (2008) applied sulphated Sepiella maindroni ink polysaccharide (SIP-SII) to human ovarian carcinoma cells SKOV3 and human umbilical vein vascular endothelial cells ECV304, and their results suggested that SIP-SII might oppress the migration and invasion of carcinoma cells via inhibition of matrix metalloproteinases-2 (MMP-2) proteolytic activity. Zong et al. (2013) found that SIP-SII has anti-metastatic and anti-angiogenic properties, which also result in the depression of the invasion and migration of carcinoma cells. Changlong et al. (1999) revealed that squid ink and its extracts might activate immunity of cells by stimulating natural killer cells and macrophages to kill tumour cells indirectly. Table 2 represents the different studies on anticancer properties of cephalopods ink. Most of the anticancer studies of cephalopods ink were done against different cell lines to measure the anticancer properties. The ink had been used in a different mode and good anticarcinogenic effect was found in almost all cases shown in Table 2.

\subsection{Antioxidant activity}

Squid and cuttlefish ink have antioxidant properties that reside in both the melanin and melanin-free fractions of the ink (Derby, 2014). Liu et al. (2011) studied the antioxidant activity of squid ink on growing broiler chickens by mixing ink in their diet. Total SOD (Superoxide dismutase) activity and MDA (malondialdehyde) content determination results showed strong antioxidant abilities of squid ink. Vate and
Benjakul (2013) studied the melanin-free ink from the splendid squid Loligo formosana. They performed differently in vitro antioxidant tests, including DPPH radical scavenging activity, ABTS radical scavenging activity, ferric reducing antioxidant power (FRAP) and chelating activity towards $\mathrm{Fe}^{2+}$, and found good antioxidant value in the melanin-free squid ink.

Sun et al. (2011) studied the polysaccharides extracted from squid ink by alkaline protease and tested for the antioxidant activities using $\mathrm{DPPH}$, radical scavenging and a FRAP assay and found a high amount of antioxidant value from the extracted polysaccharides. Chen et al. (2007) removed the melanin from squid ink, and a free radical scavenging activity test was conducted on the removed melanin. They showed that squid melanin scavenge hydroxyl free radical remarkably which are indicators of the antioxidant properties of squid melanin. Lin and Chen (2005) also isolated melanin from cuttlefish (Sepia) ink and investigated the antioxidant properties, and they found high antioxidant value. Lei et al. (2008) also found antioxidant effects of melanin-Fe squid ink when they were using it as a treatment for iron deficiency anaemia (IDA) in rats.

Fahmy and Soliman (2013) investigated the antioxidant activity of cuttlefish ( $S$. officinalis) ink extract using 1,1-diphenyl-2-picrylhydrazyl (DPPH) scavenging and lipid peroxidation assays and measured promising antioxidant properties from the Sepia ink extract. Another study by Soliman et al. (2015) was conducted to compare the antioxidant and anti-cancer activities to 5-fluorouracil (5-Fu) in vivo, where Swiss albino mice were used as experimental animals, and they found good antioxidant properties.

An in vivo study was conducted by Saleh et al. (2015) and provided information on the complications of hepatic fibrosis associated with bile duct ligation (BDL) and the potential curative role of $S$. officinalis ink extract in hepatic damage induced by BDL. The result showed a significant reduction in oxidative stress, which proves the antioxidant activity of the ink extracts. Another in vivo study provided information that cuttlefish ink increases the antioxidant level in mice (Lei et al., 2007). Studies on antioxidant properties of cephalopod inks are listed in Table 3. Both in vitro and in vivo studies had been done to determine the antioxidant properties of cephalopod ink. The mode of antioxidant studies is given in Table 3.

\section{Other properties of cephalopod ink}

Squid (L. duvauceli) and cuttlefish (Sepiella inermis) ink have antiretroviral activities, which were reported by Rajaganpathi et al. (2000). Squid ink has anti- 
Table 2. Anti-cancer properties of cephalopod ink

\begin{tabular}{|c|c|c|c|c|}
\hline $\begin{array}{c}\text { Name of } \\
\text { Cephalopods }\end{array}$ & Mode of Ink used & $\begin{array}{c}\text { Name of assay and cell line } \\
\text { used for study }\end{array}$ & Findings and Future concerns & References \\
\hline $\begin{array}{l}\text { Squid (L. } \\
\text { duvauceli) }\end{array}$ & $\begin{array}{l}\text { - } \text { Fridge dried crude ink } \\
\text { - Partially purified ink by } \\
\text { ammonium sulphate }\end{array}$ & $\begin{array}{l}\text { MTT assay (Cell viability } \\
\text { and cell proliferation } \\
\text { assay) } \\
\text { - HepG2 cell line }\end{array}$ & $\begin{array}{l}\text { - Partially purified ink } \\
\text { showed good } \\
\text { anticarcinogenic activity } \\
\text { against HepG2 cell line. } \\
\text { - Can be used treating } \\
\text { Hepatic cancer }\end{array}$ & $\begin{array}{l}\text { Diaz et al. } \\
(2014)\end{array}$ \\
\hline $\begin{array}{l}\text { Squid }(O . \\
\text { bartrami })\end{array}$ & $\begin{array}{l}\text { - Gel filtrated melanin free } \\
\text { ink sulfated by } \mathrm{PySO}_{3}\end{array}$ & $\begin{array}{l}\text { - MTT assay } \\
\text { - The human hepatocellular } \\
\text { liver carcinoma cell line } \\
\text { (HepG2) }\end{array}$ & $\begin{array}{l}\text { - Showed dose-dependent } \\
\text { suppression of cell } \\
\text { invasion and migration in } \\
\text { HepG2. } \\
\text { - Can be a potential } \\
\text { candidate for the } \\
\text { prevention of tumor } \\
\text { metastasis. }\end{array}$ & $\begin{array}{l}\text { Chen et al. } \\
\text { (2010) }\end{array}$ \\
\hline $\begin{array}{l}\text { Cuttlefish }(S . \\
\text { pharaonis })\end{array}$ & $\begin{array}{l}\text { Crude ink delipidated with } \\
\text { acetone then gel filtrated to } \\
\text { get purified peptidoglycan } \\
\text { fraction }\end{array}$ & $\begin{array}{l}\text { - } \text { MTT assay } \\
\text { - Comet assay } \\
\text { - Cervical cancer cell lines } \\
\text { (HeLa and Caski) }\end{array}$ & $\begin{array}{l}\text { - Showed significant } \\
\text { anticancer activity } \\
\text { - Can be a potential drug for } \\
\text { treating cervical cancer }\end{array}$ & $\begin{array}{l}\text { Senan et al. } \\
\text { (2013a) }\end{array}$ \\
\hline $\begin{array}{l}\text { Cuttlefish (S. } \\
\text { officinalis) }\end{array}$ & $\begin{array}{l}\text { - Crude ink aqueous extract } \\
\text { was lyophilized }\end{array}$ & $\begin{array}{l}\text { - Sulphorhodamine B (SRB) } \\
\text { method } \\
\text { - HepG2 cell line }\end{array}$ & $\begin{array}{l}\text { - Results showed good } \\
\text { cytotoxicity against the cell } \\
\text { line which may lead it as a } \\
\text { potential anticancer drug. }\end{array}$ & $\begin{array}{l}\text { Fahmy et } \\
\text { al. (2013) }\end{array}$ \\
\hline $\begin{array}{l}\text { Cuttlefish }(S . \\
\text { officinalis })\end{array}$ & - Crude ink & $\begin{array}{l}\text { - MTT assay } \\
\text { - Human glioblastoma cells } \\
\text { U87 }\end{array}$ & $\begin{array}{l}\text { - Showed cytotoxicity } \\
\text { against the cell line }\end{array}$ & $\begin{array}{l}\text { Ellouze } e t \\
\text { al. }(2015)\end{array}$ \\
\hline $\begin{array}{l}\text { Cuttlefish }(S . \\
\text { pharaonis })\end{array}$ & $\begin{array}{l}\text { - Crude ink delipidated with } \\
\text { acetone and extracted with } \\
\text { Tris- } \mathrm{HCl} \text { followed by } \\
\text { lyophilization }\end{array}$ & $\begin{array}{l}\text { - Cell viability assay using } \\
\text { Trypan Blue } \\
\text { - Ethidium bromide /acridine } \\
\text { orange staining } \\
\text { - Chick embryo fibroblasts } \\
\text { cells }\end{array}$ & $\begin{array}{l}\text { - Ink of Sepia pharaonis } \\
\text { showed highest } \\
\text { antiproliferative activity } \\
\text { - Found therapeutic potential } \\
\text { of the ink as an anticancer } \\
\text { agent. }\end{array}$ & $\begin{array}{l}\text { Senan et al. } \\
(2013 \mathrm{~b})\end{array}$ \\
\hline
\end{tabular}

aculeata)

\begin{tabular}{|c|c|c|c|c|}
\hline $\begin{array}{l}\text { Squid }(L . \\
\text { duvauceli) }\end{array}$ & & & & \\
\hline $\begin{array}{l}\text { Cuttlefish }(S . \\
\text { officinalis })\end{array}$ & - Melanin free cuttlefish ink & $\begin{array}{l}\text { - Cell viability } \\
\text { - PC12 cell line and Caco2 } \\
\text { cell line } \\
\end{array}$ & $\begin{array}{l}\text { - Showed good result against } \\
\text { the cell lines. }\end{array}$ & $\begin{array}{l}\text { Russo et al. } \\
\text { (2003) }\end{array}$ \\
\hline $\begin{array}{l}\text { Cuttlefish } \\
\text { (Sepia } \\
\text { esculenta) }\end{array}$ & $\begin{array}{l}\text { - Oligopeptide isolated from } \\
\text { hydrolysates of Sepia ink }\end{array}$ & $\begin{array}{l}\text { - Cell viability using CCK-8 } \\
\text { assay } \\
\text { - Human prostate carcinoma } \\
\text { cell, DU-145 }\end{array}$ & $\begin{array}{l}\text { - Gln-Pro-Lys peptide } \\
\text { showed significant effect } \\
\text { against DU-145 cell line. } \\
\text { - Potential antitumor agent }\end{array}$ & $\begin{array}{l}\text { Guo-Fang } \\
\text { et al. }(2011)\end{array}$ \\
\hline $\begin{array}{l}\text { Cuttlefish } \\
\text { (Sepia } \\
\text { mendroni) }\end{array}$ & $\begin{array}{l}\text { Ink polysaccharide (SIP) } \\
\text { isolated from the ink by } \\
\text { enzymolysis, anion- } \\
\text { exchange and gel- } \\
\text { permeation } \\
\text { chromatography. }\end{array}$ & $\begin{array}{l}\text { - } \text { MTT assay } \\
\text { - Cell viability analysis by } \\
\text { trypan blue exclusion } \\
\text { - } \text { Human ovarian carcinoma } \\
\text { cell line SKOV3 and } \\
\text { human umbilical vein } \\
\text { vascular endothelial cell } \\
\text { line (HUVEC) ECV304 } \\
\end{array}$ & $\begin{array}{l}\text { - Findings from this study } \\
\text { suggested good anticancer } \\
\text { activity against human } \\
\text { carcinoma cells. }\end{array}$ & $\begin{array}{l}\text { Wang et al. } \\
(2008)\end{array}$ \\
\hline $\begin{array}{l}\text { Cuttlefish }(S . \\
\text { mendroni })\end{array}$ & $\begin{array}{l}\text { Oligopeptide isolated from } \\
\text { hydrolysates of Sepia ink }\end{array}$ & $\begin{array}{l}\text { - Cell viability using CCK-8 } \\
\text { assay } \\
\text { - Human prostate carcinoma } \\
\text { cell, DU-145, PC-3 and } \\
\text { LNCaP cells }\end{array}$ & $\begin{array}{l}\text { - Good anticarcinogenic } \\
\text { properties found in the ink } \\
\text { sample. }\end{array}$ & $\begin{array}{l}\text { Huang et al. } \\
\text { (2012) }\end{array}$ \\
\hline
\end{tabular}


Table 3. Antioxidant properties of cephalopod ink

\begin{tabular}{|c|c|c|c|c|c|}
\hline $\begin{array}{l}\text { Name of the } \\
\text { cephalopods }\end{array}$ & Mode of ink & $\begin{array}{l}\text { Types of } \\
\text { experimental models } \\
\text { for determining } \\
\text { antioxidant activity }\end{array}$ & $\begin{array}{l}\text { Methods of determining } \\
\text { Antioxidant activity }\end{array}$ & Results & References \\
\hline Cuttlefish & $\begin{array}{l}\text { - Crude ink } \\
\text { diluted and } \\
\text { mixed with } \\
\text { boiler diet in } \\
\text { different } \\
\text { concentration }\end{array}$ & $\begin{array}{l}\text { - In vivo } \\
\text { - Arbor Acres } \\
\text { broiler chicken } \\
\text { was used }\end{array}$ & $\begin{array}{ll}\text { - } & \text { Total SOD } \\
\text { (Superoxide } \\
\text { dismutase) activity } \\
\text { determination } \\
\text { - MDA } \\
\text { (malondialdehyde) } \\
\text { content } \\
\text { determination }\end{array}$ & $\begin{array}{l}\text { High dose of ink } \\
\text { showed good SOD } \\
\text { activity on broiler } \\
\text { chicken serum } \\
\text { - Also reduced MDA } \\
\text { level significantly. }\end{array}$ & $\begin{array}{l}\text { Liu et al. } \\
\text { (2011) }\end{array}$ \\
\hline \multirow[t]{2}{*}{$\begin{array}{l}\text { Spendid Squid } \\
\text { (Loligo } \\
\text { formosana })\end{array}$} & $\begin{array}{l}\text { - Melanin free } \\
\text { ink was used } \\
\text { for different } \\
\text { antioxidant } \\
\text { test }\end{array}$ & - In vitro assays & $\begin{array}{l}\text { - } \text { DPPH radical } \\
\text { scavenging activity } \\
\text { - } \text { ABTS radical } \\
\text { scavenging activity } \\
\text { - } \text { Ferric reducing } \\
\text { antioxidant power } \\
\text { - Chelating activity } \\
\text { toward } \mathrm{Fe}^{2+}\end{array}$ & \multirow{2}{*}{$\begin{array}{l}\text { - Good antioxidant } \\
\text { properties were } \\
\text { found in vitro } \\
\text { assays. } \\
\text { - High concentration } \\
\text { of melanin free ink } \\
\text { shows good } \\
\text { antioxidant activity } \\
\text { on different model } \\
\text { systems for } \\
\text { determining } \\
\text { antioxidant activity }\end{array}$} & \multirow[t]{2}{*}{$\begin{array}{c}\text { Vate and } \\
\text { Benjakul } \\
(2013)\end{array}$} \\
\hline & & $\begin{array}{l}\text { - Different Model } \\
\text { systems }\end{array}$ & $\begin{array}{l}\text { - } \beta \text {-Carotene-linoleate } \\
\text { model system } \\
\text { - Lecithin liposome } \\
\text { system } \\
\text { - Fish mince model } \\
\text { system }\end{array}$ & & \\
\hline $\begin{array}{c}\text { Squid } \\
\text { (Ommastrephes } \\
\text { bartrami) }\end{array}$ & $\begin{array}{l}\text { - } \text { Squid ink } \\
\text { melanin-Fe } \\
\text { mixed with } \\
\text { diet }\end{array}$ & $\begin{array}{l}\text { - In vivo } \\
\text { - Early weaned } \\
\text { male Wistar rats } \\
\text { (4 weeks old) } \\
\text { were used }\end{array}$ & $\begin{array}{l}\text { - } \text { Total SOD } \\
\text { (Superoxide } \\
\text { dismutase) activity } \\
\text { determination } \\
\text { - GSH-Px } \\
\text { (Glutathione } \\
\text { peroxidase) activity } \\
\text { determination } \\
\text { - MDA } \\
\text { (malondialdehyde) } \\
\text { content } \\
\text { determination } \\
\end{array}$ & $\begin{array}{l}\text { - SOD and GSH-Px } \\
\text { activity increased } \\
\text { while MDA content } \\
\text { decreases in the } \\
\text { serum of the rats. }\end{array}$ & $\begin{array}{l}\text { Lei et al. } \\
(2008)\end{array}$ \\
\hline $\begin{array}{l}\text { Cuttlefish }(S . \\
\text { officinalis })\end{array}$ & $\begin{array}{l}\text { Crude ink } \\
\text { aqueous } \\
\text { extract was } \\
\text { lyophilized }\end{array}$ & $\begin{array}{l}\text { - In vitro } \\
\text { - In vivo (Male } \\
\text { albino rats) } \\
\text { - Divided into two } \\
\text { groups the Sham- } \\
\text { operated control } \\
\text { and bile duct } \\
\text { ligated (BDL) } \\
\text { group }\end{array}$ & $\begin{array}{ll}\text { - } & \text { DPPH radical } \\
\text { scavenging activity }\end{array}$ & $\begin{array}{l}\text { - Significant reduction } \\
\text { of oxidative stress } \\
\text { was found on BDL } \\
\text { group after } \\
\text { treatment with sepia } \\
\text { ink }\end{array}$ & $\begin{array}{l}\text { Saleh et al. } \\
\quad(2015)\end{array}$ \\
\hline Cuttlefish & $\begin{array}{l}\text { Ink was } \\
\text { hydrolyzed } \\
\text { by proteinase } \\
\text { enzyme and } \\
\text { vacuum dried } \\
\text { prior to use }\end{array}$ & $\begin{array}{l}\text { - In vivo } \\
\text { - Healthy female } \\
\text { ICR mice divided } \\
\text { into five groups }\end{array}$ & - Total SOD activity & $\begin{array}{l}\text { - Results showed } \\
\text { increased } \\
\text { antioxidant level in } \\
\text { mice serum. }\end{array}$ & $\begin{array}{l}\text { Lei et al. } \\
(2007)\end{array}$ \\
\hline
\end{tabular}


Table 3 (Continued). Antioxidant properties of cephalopod ink

\begin{tabular}{|c|c|c|c|c|c|}
\hline $\begin{array}{l}\text { Name of the } \\
\text { cephalopods }\end{array}$ & Mode of ink & $\begin{array}{c}\text { Types of } \\
\text { experimental models } \\
\text { for determining } \\
\text { antioxidant activity }\end{array}$ & $\begin{array}{l}\text { Methods of determining } \\
\text { Antioxidant activity }\end{array}$ & Results & References \\
\hline $\begin{array}{c}\text { Cuttlefish }(S . \\
\text { officinalis })\end{array}$ & $\begin{array}{l}\text { Crude ink } \\
\text { aqueous } \\
\text { extract was } \\
\text { lyophilized }\end{array}$ & - In vitro & $\begin{array}{l}\text { - } \text { FRAP assay } \\
\text { - Lipid peroxidation } \\
\text { assay }\end{array}$ & $\begin{array}{l}\text { - Significant } \\
\text { antioxidant activity } \\
\text { found in cuttlefish } \\
\text { ink }\end{array}$ & $\begin{array}{l}\text { Fahmy et } \\
\text { al. (2013) }\end{array}$ \\
\hline $\begin{array}{l}\text { Cuttlefish } \\
\text { (Sepia } \text { spp.) }\end{array}$ & $\begin{array}{l}\text { - Melanin } \\
\text { isolated from } \\
\text { the ink }\end{array}$ & - In vitro & $\begin{array}{l}\text { - Ferric thiocyanate } \\
\text { method } \\
\text { - Ferric reducing } \\
\text { antioxidant power } \\
\text { (FRAP) } \\
\text { - Chelating activity } \\
\text { toward } \mathrm{Fe}^{2+}\end{array}$ & $\begin{array}{l}\text { - High melanin } \\
\text { concentration } \\
\text { showed good } \\
\text { antioxidant activity }\end{array}$ & $\begin{array}{l}\text { Lin and } \\
\text { Chen } \\
(2005)\end{array}$ \\
\hline
\end{tabular}

inflammatory effects, which were studied by Mimura et al. (1987). Low molecular weight melano proteins were obtained from Ommastrephes bartrami ink and studied for anti-inflammatory effects using carrageenan-induced rat paw oedema. In addition, Fahmy and Soliman (2013) also found anti-inflammatory effects of cuttlefish (Sepia) ink.

Kim et al. (2003) extracted and purified an angiotensin-converting enzyme from squid ink which can dilate blood vessels and lower blood pressure. According to Mimura et al. (1982) squid ink has strong anti-ulcerogenic properties. Melanin extracts constitute almost $90 \%$ of squid ink and could inhibit gastric secretion in rats. The molecular weight of melano protein that is contained in the active fractions might be responsible for the anti-ulcerogenic activity, by enhancing the glycoprotein activity of gastric mucosa. In addition to the above properties, Sepia ink also has antineoplastic properties (Soliman et al., 2015) and plasma coagulation properties (Vennila et al., 2010) which make it an attractive element among researchers.

\section{Conclusion}

Compared to synthetic products, natural bioactive products have the fewest side effects, and the marine environment can be a good source of natural bioactive products. Among different marine products, cephalopod ink is one of the best sources of bioactive products. Different studies which were demonstrated in this study provide information about the neutraceuticals properties of the cephalopods ink. This review also collaborates information about various modes of using the ink with methodology, which can be helpful for future researchers to conduct a new research. Functional and nutraceutical properties of cephalopods ink are mainly focused in this study so that awareness on using cephalopods ink can be built up. In the near future, it is hoped that this can reduce the wastage of the ink industrially. Proper consciousness on its variety of medicinal and therapeutic properties will make the ink an attractive object for preparing functional food and alternative medicine.

\section{Conflict of interest statement}

We declare that we have no conflict of interest.

\section{Acknowledgments}

This material is upon work supported by a grant number 304/PTEKIND/6316062 obtained from Universiti Sains Malaysia (USM).

\section{References}

Boletzky, V.S. (1987). Juvenile behavior. In Boyle, P.R. (Ed.) Cephalopod Life Cycles, p. 45-84. London: Academic Press.

Bush, S.L. and Robison, B.H. (2007). Ink utilization by mesopelagic squid. Marine Biology, 152(3), 485494. https://doi.org/10.1007/s00227-007-0684-2

Changlong, L., Shen, H. and Beixing, L. (1999). The immuno-stimulating activations of squid ink and its extracts. Chinese Journal of Marine Drugs, 18(2), 32 -34 .

Chen, S.G., Xue, C.H., Xue, Y., Li, Z.J., Gao, X. and Ma, Q. (2007). Studies on the free radical scavenging activities of melanin from squid ink. Chinese Journal of Marine Drugs, 26, 24-27

Chen, S., Wang, J., Xue, C., Li, H., Sun, B., Xue, Y. and Chai, W. (2010). Sulfation of a squid ink polysaccharide and its inhibitory effect on tumor cell metastasis. Carbohydrate Polymers, 81(3), 560-566. https://doi.org/10.1016/j.carbpol.2010.03.009

Cornell, J.J. and Handy, R. (1982). Trends in fish utilization, p. 30-31. England: Fishery news books. 
Derby, C.D. (2014). Cephalopod ink: production, chemistry, functions and applications. Marine Dugs, 12(5), 2700-2730. https://doi.org/10.3390/ md12052700

Diaz, J.H.J. and Thilaga, R.D. (2016). Screening of Antimicrobial Activities In The Ink of Cephalopods Against Human Pathogens. Drugs, 1(2), 3-4.

Diaz, J.H.J., Thilaga, R.D. and Sivakumar, V. (2014). Cytotoxic activity of crude and partially purified ink of L. duvauceli towards HepG2cell line. International Journal of Pharma Research and Review, 3(6), 19-23.

Fahmy, S.R. and Soliman, A.M. (2013). In vitro antioxidant, analgesic and cytotoxic activities of Sepia officinalis ink and Coelatura aegyptiaca extracts. African Journal of Pharmacy and Pharmacology, 7(22), 1512-1522. https:// doi.org/10.5897/AJPP2013.3564

Girija, A.S., Suba, K.P., Hariprasad, G. and Raghuraman, R. (2014). A novel study on the antibacterial effect of the crude squid ink extracts from the Indian squid against four bacterial pathogens isolated from carious dentine. International Journal of Current Microbiology and Applied Sciences, 3(4), 904-911.

Girija, S.A.S., Hariprasad, G., Priyadharsini, V.J., Suba, P.K., Raghuraman, R. and Gnanavendhan, S.G. (2008). Antimicrobial potential of Loligo duvauceli ink against the common clinical bacterial and yeast isolates. Biomedicine, 28(3), 213-215.

Giriji, S., Priyadharshini, J.V., Suba, P.K., Hariprasad, G. and Raghuraman, R. (2011). Isolation and characterization of lolduvin-S: A novel antimicrobial protein from the Ink of Indian Squid Loligo duvauceli. International Journal of Current Research, 3(7), 4-14.

Guo-Fang, D., Huang, F.F., Zui-Su, Y.A.N.G., Di, Y.U. and Yong-Fang, Y.A.N.G. (2011). Anticancer activity of an oligopeptide isolated from hydrolysates of Sepia ink. Chinese Journal of Natural Medicines, 9(2), 151-155.

Hanlon, R.T. and Messenger, J.B. (1996). Cephalopod behaviour. $1^{\text {st }}$ ed. United Kingdom: Cambridge University Press.

Hoque, M.S., Benjakul, S. and Prodpran, T. (2010). Effect of heat treatment of film-forming solution on the properties of film from cuttlefish (Sepia pharaonis) skin gelatin. Journal of Food Engineering, 96(1), 66-73. https://doi.org/10.1016/ j.jfoodeng.2009.06.046

Huang, F., Yang, Z., Yu, D., Wang, J., Li, R. and Ding, G. (2012). Sepia ink oligopeptide induces apoptosis in prostate cancer cell lines via caspase-3 activation and elevation of $\mathrm{Bax} / \mathrm{Bcl}-2$ ratio. Marine drugs, 10 (10), 2153-2165. https://doi.org/10.3390/ md10102153

Karim, N.U., Sadzali, N.L. and Hassan, M. (2016). Effects of squid ink as edible coating on squid sp. (Loligo duvauceli) spoilage during chilled storage. International Food Research Journal, 23(5), 1895-1901.

Kim, S.Y., Kim, S.H. and Song, K.B. (2003). Partial purification and characterization of an angiotensinconverting enzyme inhibitor from squid ink. Agricultural Chemistry and Biotechnology, 46 (3), 122-133.

Lei, M., Wang, J.F., Wang, Y.M., Pang, L., Wang, Y., $\mathrm{Xu}, \mathrm{W}$. and Xue, C.H. (2007). Study of the radioprotective effect of cuttlefish ink on hemopoietic injury. Asia Pacific Journal of Clinical Nutrition, 16 (S1), 239-243.

Lei, M., Xue, C.H., Wang, Y.M., Li, Z.J., Xue, Y. and Wang, J.F. (2008). Effect of Squid Ink Melanin-Fe on Iron Deficiency Anemia Remission. Journal of Food Science, 73(8), H207-H211. https:// doi.org/10.1111/j.1750-3841.2008.00930.x

Lin, L.C. and Chen, W.T. (2005). The study of antioxidant effects in melanins extracted from various tissues of animals. Asian-Australasian Journal of Animal Science, 18(2), 277-281. https:// doi.org/10.5713/ajas.2005.277

Liu, H., Luo, P., Chen, S. and Shang, J. (2011). Effects of squid ink on growth performance, antioxidant functions and immunity in growing broiler chickens. Asian-Australasian Journal of Animal Sciences, 24(12), 1752-1756. https:// doi.org/10.5713/ajas.2011.11128

Lucero, M.T., Farrington, H. and Gilly, W.F. (1994). Quantification of L-dopa and dopamine in squid ink: implications for chemoreception. The Biological Bulletin, 187(1), 55-63. https:// doi.org/10.2307/1542165

McConnell, O.J., Longley, R.E. and Koehn, F.E. (1993). The discovery of marine natural products with therapeutic potential. Biotechnology (Reading, Mass.), 26, 109-174.

Mimura, T., Maeda, K., Hariyama, H., Aonuma, S., Satake, M. and Fujita, T. (1982). Studies on biological activities of melanin from marine animals. I. Purification of melanin from Ommastrephes bartrami Lesuel and its inhibitory activity on gastric juice secretion in rats. Chemical and Pharmaceutical Bulletin, 30(4), 1381-1386. https:// doi.org/10.2307/1542165 
Mimura, T., Itoh, S., Tsujikawa, K., Nakajima, H., Satake, M., Kohama, Y. and Okabe, M. (1987). Studies on biological activities of melanin from marine animals. V. Anti-inflammatory activity of low-molecular-weight melanoprotein from squid (Fr. SM II). Chemical Pharmaceutical Bulletin, 35(3), 1144-1150. https://doi.org/10.1248/cpb.35.1144

Mochizuki, A. (1979). An antiseptic effect of cuttlefish ink. Nippon Suisan Gakkaishi, 45(11), 1401-1403. https://doi.org/10.2331/suisan.45.1401

Nair, P. and Sherief, P.M. (2010). Antibacterial activity in the accessory nidamental gland extracts of the Indian squid, Loligo duvauceli Orbigny. Indian Journal of Marine Science, 39(1), 100-104.

Naraoka, T., Chung, H.S., Uchisawa, H., Sasaki, J.I. and Matsue, H. (2000). Tyrosinase activity in antitumor compounds of squid ink. Food Science and Technology Research, 6(3), 171-175. https:// doi.org/10.3136/fstr.6.171

Nicomrat, D. and Tharajak, J. (2015). Antimicrobial Effect of Squid Ink on Common Microbial Causing Biofilm Attaching to Silicone. In Yimnirun, R. (Ed.) Applied Mechanics and Materials. Vol. 804, p. 191194. Switzerland: Trans Tech Publications. https:// doi.org/10.4028/www.scientific.net/AMM.804.191

Nirmale, V., Nayak, B.B., Kannappan, S. and Basu, S. (2002). Antibacterial effect of the Indian squid, Loligo duvauceli (d'Orbigny), ink. Journal of the Indian Fisheries Association, 29, 65-69.

Nishimoto, J., Motohiro, T., Oomori, H., Kuizumi, C., Tamoto, H. Kakehashi, K., Shimuzu, H. and Kobatake, A. (1980). Shiokara (salted and fermented seafoods). In Shin Suisangaku Zenshu 25, Suisan Kakou Gijutsu Kouseisha - Kouseisha, p. 240 -244 . Tokyo

Nithya, M., Ambikapathy, V. and Panneerselvam, A. (2011). Effect of pharaoh's cuttlefish ink against bacterial pathogens. Asian Journal Plant Scientific Research, 1(4), 49-55.

Ortonne, J.P., Voulot, C., Khatchadourian, C., Palumbo, A. and Prota, G. (1981). A reexamination of melanogenesis in the ink gland of cephalopods. In Seiji, M. (Ed.) Pigment Cell 1981: Phenotypic Expression in Pigment Cells, p. 49-57. Tokyo: University of Tokyo Press.

Palumbo, A., Di Cosmo, A. and Gesualdo, I. (1997). A Calcium-Dependent Nitric Oxide Synthase and NMDA R1 Glutamate Receptor in the Ink Gland of Sepia officinalis: A Hint to a Regulatory Role of Nitric Oxide in Melanogenesis? Biochemical and Biophysical Research Communications, 235(2), 429432. https://doi.org/10.1006/bbrc.1997.6734
Palumbo, A., Gesualdo, I., Di Cosmo, A. and De Martino, L. (1998). The Ink Gland of Sepia officinalis as Biological Model for Investigations of Melanogenesis. In New Developments in Marine Biotechnology, p. 147-149. US: Springer. https:// doi.org/10.1007/978-1-4757-5983-9_32

Palumbo, A., Poli, A., Di Cosmo, A. and d'Ischia, M. (2000). N-Methyl-d-aspartate Receptor Stimulation Activates Tyrosinase and Promotes Melanin Synthesis in the Ink Gland of the Cuttlefish Sepia officinalis through the Nitric Oxide/cGMP Signal Transduction Pathway A Novel Possible Role for Glutamate as Physiologic Activator of Melanogenesis. Journal of Biological Chemistry, 275(22), 16885-16890. https:// doi.org/10.1074/jbc.M909509199

Rajaganapathi, J., Thyagarajan, S.P. and Edward, J.K. (2000). Study on cephalopod's ink for anti-retroviral activity. Indian Journal of Experimental Biology, 38, 519-520.

Rao, K.V. (1954). Biology and fishery of the Palk-Bay squid, Sepioteuthis arctipinnis Gould. Indian Journal of Fisheries, 1(1 and 2), 37-66.

Russo, G.L., De Nisco, E., Fiore, G., Di Donato, P., d'Ischia, M. and Palumbo, A. (2003). Toxicity of melanin-free ink of Sepia officinalis to transformed cell lines: identification of the active factor as tyrosinase. Biochemical and Biophysical Research Communications, 308(2), 293-299. https:// doi.org/10.1016/S0006-291X(03)01379-2

Sadok, S., Abdelmoulah, A. and El Abed, A. (2004). Combined effect of sepia soaking and temperature on the shelf life of peeled shrimp Penaeus kerathurus. Food Chemistry, 88(1), 115-122. https:// doi.org/10.1016/j.foodchem.2003.12.031

Saleh, H., Soliman, A.M., Mohamed, A.S. and Marie, M.A.S. (2015). Antioxidant effect of sepia ink extract on extrahepatic cholestasis induced by bile duct ligation in rats. Biomedical and Environmental Sciences, 28(8), 582-594.

Sasaki, J.I., Ishita, K., Takaya, Y., Uchisawa, H. and Matsue, H. (1997). Anti-tumor activity of squid ink. Journal of Nutritional Science and Vitaminology, 43(4), 455-461. https:// doi.org/10.3177/jnsv.43.455

Senan, V.P., Sherief, P.M. and Nair, J.R. (2013a). Anticancer property of purified fraction $\mathrm{C} 2$ of cuttlefish (Sepia pharaonis) ink on cervical cancer cells. Indo American Journal of Pharmaceutical Research, 3(9), 7444-54.

Senan, V.P., Sherief, P.M. and Nair, J.R. (2013b). Cytotoxic effect of ink extracts of cuttlefish and 
squid on chick embryo fibroblasts. International Journal of Pharmaceutical Sciences and Research, 4 (5), 1893-1896.

Silas, E.G. and Pillai, P.P. (1982). Resources of tunas and related species and their fisheries in the Indian Ocean. In Central Marine Fisheries Research Institute Bulletin. Vol.32, p. 1-174. India: Indian Council of Agricultural Research.

Soliman, A.M., Fahmy, S.R. and El-Abied, S.A. (2015). Anti-neoplastic activities of sepia officinalis ink and coelatura aegyptiaca extracts against Ehrlich ascites carcinoma in Swiss albino mice. International Journal of Clinical and Experimental Pathology, 8 (4), 3543-3555.

Sun, N.N., Li, H.S., Zhang, L.Y., Lei, J. and Zheng, X.M. (2011). Extraction and Antioxidant Activity of Polysaccharides from Squid Ink [J]. Food Science, 32, 95-99

Sundaram, S. (2009). Various uses of cephalopods. Fishing Chimes, 29(8), 23-25.

Takai, M., Kawai, Y., Inoue, N. and Shinano, H. (1992). Comparative studies on microbiological and chemical characteristics of "ika-shiokara akazukuri" and "ika-shiokara kurozukuri". Nippon Suisan Gakkaishi, 58(12), 2373-2378. https:// doi.org/10.2331/suisan.58.2373

Takai, M., Yamazaki, K., Kawai, Y., Inoue, N. and Shinano, H. (1993). Effect of squid liver, skin, and ink on microbiological characteristics of "Ikashiokara" during ripening process. Nippon Suisan Gakkaishi, 59(9), 1617-1623. https:// doi.org/10.2331/suisan.59.1617

Takaya, Y., Uchisawa, H., Matsue, H., Okuzaki, B., Narumi, F., Sasaki, J. and Ishida, K. (1994). An investigation of the antitumor peptidoglycan fraction from squid ink. Biological and Pharmaceutical Bulletin, 17(6), 846-849. https://doi.org/10.1248/ bpb.17.846

Vate, N.K. and Benjakul, S. (2013). Antioxidative activity of melanin-free ink from splendid squid (Loligo formosana). International Aquatic Research, 5, 9. https://doi.org/10.1186/2008-6970-59

Vennila, R., Kanchana, S., Arumugam, M. and Balasubramanian, T. (2010). Investigation of antimicrobial and plasma coagulation property of some molluscan ink extracts: Gastropods and cephalopods. African Journal of Biochemistry Research, 5(1), 14-21.

Vijayakumaran, K. (1984). Dried squids-An insight into the economics of production with special reference to south-east coast. Fishing Chimes, 23(1), 32-35.
Voss, G.L. (1963). Cephalopods of the Philippine Islands. Vol. 234, p. 1-180. United States National Museum: Bulletin of the United States National Museum. https://doi.org/10.5479/si.03629236.234.1

Wang, S., Cheng, Y., Wang, F., Sun, L., Liu, C., Chen, G. and Qu, X. (2008). Inhibition activity of sulfated polysaccharide of Sepiella maindroni ink on matrix metalloproteinase (MMP)-2. Biomedicine and Pharmacotherapy, 62(5), 297-302. https:// doi.org/10.1016/j.biopha.2008.01.018

Yang, H., Johnson, P.M., Ko, K.C., Kamio, M., Germann, M.W., Derby, C.D. and Tai, P.C. (2005). Cloning, characterization and expression of escapin, a broadly antimicrobial FAD-containing L-amino acid oxidase from ink of the sea hare Aplysia californica. Journal of Experimental Biology, 208 (18), 3609-3622. https://doi.org/10.1242/jeb.01795

Zhong, J.P., Wang, G., Shang, J.H., Pan, J.Q., Li, K., Huang, Y. and Liu, H.Z. (2009). Protective effects of squid ink extract towards hemopoietic injuries induced by cyclophosphamine. Marine Drugs, 7(1), 9-18. https://doi.org/10.3390/md7010009

Zong, A., Zhao, T., Zhang, Y., Song, X., Shi, Y., Cao, H. and Wang, F. (2013). Anti-metastatic and antiangiogenic activities of sulfated polysaccharide of Sepiella maindroni ink. Carbohydrate Polymers, 91 (1), 403-409. https://doi.org/10.1016/ j.carbpol.2012.08.050 